\title{
Green synthesis of silver nanoparticles from Endophytic fungus Aspergillus niger isolated from Simarouba glauca leaf and its Antibacterial and Antioxidant activity
}

\author{
Hemashekhar $\mathrm{B}^{1}$, Chandrappa $\mathrm{C} \mathrm{P}^{1^{*}}$, Govindappa $\mathrm{M}^{2}$, Chandrasekhar $\mathrm{N}^{3}$, \\ Nagaraju Ganganagappa ${ }^{4}$ Ramachandra $\mathrm{YL}^{5}$. \\ ${ }^{I}$ Department of Biotechnology, Shridevi Institute of Engineering and Technology, Tumkur, Karnataka, India. \\ ${ }^{2}$ Department of Biotechnology, Dayananda Sagar College of Engineering, Bengaluru, Karnataka, India. \\ ${ }^{3}$ Department of Chemistry, Shridevi Institute of Engineering and Technology, Tumkur, Karnataka, India. \\ ${ }^{4}$ Department of Chemistry, Siddaganga Institute of Technology, Tumkur, Karnataka, India. \\ ${ }^{5}$ Department of Biotechnology and Bioinformatics, Kuvempu University, Shankara Ghatta, Shimoga, \\ Karnataka, India \\ Corresponding author: Chandrappa C P
}

\section{ABSTRACT}

The field of nanotechnology is the most promising area of the research. In our present study we report the biological method of synthesis of silver nanoparticles by endophytic extracts isolated from the leaf of Simarouba glauca. The surface Plasmon resonance characteristic of silver nanoparticles was revealed by the UV-Vis spectrum at $400 \mathrm{~nm}$. The crystalline nature of silver nanoparticle was confirmed by X ray diffraction studies. Spherical shaped and monodispersed nanoparticles were found in Scanning electron micrograph. The average size of silver nanoparticles was $41.9 \mathrm{~nm}$ as determined by dynamic light scattering. The peak in silver region confirming the presence of elemental silver was determined by Energy dispersive X-ray spectroscopy analysis. Antibacterial activity of silver nanoparticles utilized in this study was found to be more significant than standard Taxim antibiotic against multidrug resistant bacteria such as Escherichia coli, Pseudomonas aeruginosa, Staphylococcus aureus and Klebsiella pneumonia. Endophytic based silver nanoaprticles were found to possess significant antioxidant activity.

Keywords: silver nanoparticles, endophyte, multidrug, Taxim, Antioxidant.

\section{INTRODUCTION}

Nanotechnology has acquired colossal propulsion in harmonizing metals into nanosized, shapes and controlled disparity owing to their prospective use for human benefits [1]. Due to cost effective and environment friendly nature, biological method of nanoparticles synthesis takes advantage over physical and chemical synthesis [2, 3]. For the synthesis of nanoparticles, many micro organisms such as bacteria (4), fungi (5), yeasts (6), plant extracts (7), and biological particles (8) have been exploited. As the fungi can secrete large amount of enzymes, in the synthesis of metal nanoparticles they are preferred as ideal candidates [9]. Silver is an effective antimicrobial agent with diverse in vitro and in vivo applications with greatest advantage to humans [10]. Currently topical dressing with silver based is widely used in treating chronic ulcers and open wounds [11]. Silver nanoparticles have found potential application in many fields such as, antibacterial, drug delivery, biological sensors, textiles and filters $[12,13]$. Simarouba glauca is one of the important traditional medicinal plants due to the presence alkaloids, flavonoids, carbohydrates, glycosides, a phenolic compound, tannins, terpenoids, cardenolides, saponins, fixed oils which can usually account for their therapeutic action including Antibacterial, antiviral, anti-inflammatory, antiprotozoal and antitumor activities [14]. But never synthesized and characterized silver nanoparticles by the extracts of Simarouba glauca. Therefore, In the present article we emphasizes on the synthesis of silver nanoparticles from the endophytes contained in Simarouba glauca leaf, as these endophytes harbour inter or intra cellularly with the similar characters and also using these endophytes helps in maintaining ecological balance as if the plants are used in bulk synthesis of silver nanoparticles there is the risk of endangering of the particular plant thus entering into endophytic synthesis of nanoparticles can overcome this problem. In this study we prioritize on antimitotic assay which is not yet reported for the 
silver nanoparticles synthesized from endophytic extracts.

\section{MATERIALS AND METHODS}

Isolation of endophytic fungi

Healthy leaves of Simarouba glauca were collected from Shridevi Institute of Engineering and Technology campus in month of April 2016. They were surface cleaned with running tap water to remove contaminants and incised into $0.5 \mathrm{~mm}$ pieces and surface sterilized using $0.01 \%$ mercuric chloride followed by double distilled water. The leaves were transferred onto PDA (Potato Dextrose Agar) medium and incubated for 7 days for the growth of endophytic fungi. Stock cultures and subcultures were maintained for future processes.

\section{Identification of endophytic fungi}

Endophytic fungus isolated from leaf of Simarouba glauca was identified as Aspergillus niger based on morphological characteristics, colony growth and hyphae (Fig-1).

\section{Preparation of endophytic extracts}

The mycelia of Aspergillus niger from growing edge was inoculated into $1000 \mathrm{~mL}$ Erlenmeyer flask containing $500 \mathrm{~mL}$ of Potato Dextrose broth medium and incubated for one week on a rotary shaker at $25^{\circ} \mathrm{C}$. The collected culture filtrate was filtered through a Whatman filter paper followed by centrifugation at $10,000 \mathrm{rpm}$ for $15 \mathrm{~min}$ and supernatant was collected and stored for further analysis.

\section{Synthesis of silver nanoparticles}

$5 \mathrm{ml}$ of endophytic extracts was treated with $45 \mathrm{ml}$ of aqueous $5 \mathrm{mM}$ silver nitrate in Erlenmeyer flask which was kept for incubation for a period of 24 hours at room temperature in dark condition. The endophytic extract with silver nitrate was centrifuged at $10,000 \mathrm{rpm}$ for $10 \mathrm{~min}$ where supernatant was discarded and pellate was washed repeatedly with double distilled water to washout un reacted silver nitrate and endophytic extracts. The left over pure pellate was stored for further experiments.

\section{Characterization of silver nanoparticles}

The reduction of silver ions was primarily monitored using UV visible spectroscopy (Agilent Cary 60). The analysis was performed by continuous scanning between the wavelengths of $300-700 \mathrm{~nm}$. The diffracted intensities were recorded for $2 \theta$ angles from $10^{\circ}$ to $80^{\circ}$ by XRD diffractometer RigakuSmartLab with monochromatized $\mathrm{Cu}-\mathrm{K} \alpha$ radiation. FT- IR spectra were recorded with Bruker- alpha. 100 $\mathrm{mg}$ of dried sample was mixed with $100 \mathrm{mg}$ of spectral grade $\mathrm{KBr}$ and pressed into discs under hydraulic pressure.The size and surface morphology was studied using scanning electron microscopy (Ultra 55 Model-II, Carl Zeiss SEM machine). EDX analysis was carried out to check the elemental composition of nanoparticles that gives the elemental knowledge of sample.

\section{Anti- bacterial assay}

The disc diffusion method was used to carried out antibacterial activity of silver nanoparticles on Escherichia coli, Pseudomonas aeruginosa, Staphylococcus aureus and Klebsiella pneumonia. Mackonkey broth (HiMedia) medium was used to sub culture bacteria and was incubated at $37^{\circ} \mathrm{C}$ for $24 \mathrm{~h}$. Overnight fresh cultures were collected and spread on Mackonkey agar plates to cultivated bacteria. $5 \mathrm{~mm}$ sterile discs were saturated with double distilled water, Taxim (standard antibiotic), AgNPs and endophytic extracts were placed in each plate and incubated again at $37^{\circ} \mathrm{C}$ for $24 \mathrm{~h}$. Antibacterial activity was measured based on zone of inhibition around the disc impregnated with double distilled water, Taxim (standard antibiotic), AgNPs and endophytic extracts.

\section{In vitro antioxidant activity \\ DPPH radical scavenging assay}

To determine the scavenging ability, $1 \mathrm{ml}$ of various concentrations of silver nanoparticles and ascorbic acid (standard) were prepared with $4 \mathrm{ml}$ of DPPH solution separately (15). The mixture was mixed vigorously and kept in the dark for $30 \mathrm{~min}$ before measuring the absorbance at $517 \mathrm{~nm}$ against blank. Then the scavenging activity was calculated using the following equation.

Scavenging effect $(\%)=[1$-Absorbance of sample/ Absorbance of Control] $\times 100$

\section{Antimitotic assay}

The antimitotic activity of synthesized silver nanoparticles was studied using Allium cepa root tips (16). Allium cepa root tips were treated for 48 hours with synthesized nanoparticles, quercetin $(10 \mathrm{mg} / \mathrm{ml}$, $5 \mathrm{mg} / \mathrm{ml}$; quercetin $-1 \mathrm{mg} / \mathrm{ml}$ ) and distilled water were used. The root tips were fixed with 1:3 acetoalcohol and squash with acetocarmine stain was prepared and monitored for cellular, nucleolar, and chromosomal abnormalities. The mitotic indices were determined for each root tip manually, scoring approximately 500 cells under high resolution bright field light microscopy (100 x oil immersions) and the phases were observed. Dividing cells include prophase, metaphase, anaphase, and telophase. The cells were examined for the abnormalities like chromosomal fragments, vagrant chromosomes, chromosomal gaps, anaphase, multipolar anaphases, and telophases and stick chromosomes. The mitotic index was calculated by using the formula: 
Mitotic index $=[$ Number of dividing cell $/$ Total number of cells] x $100 \%$

\section{RESULTS AND DISCUSSION}

Isolation of endophytic fungi

The isolated endophytic fungi were identified as Aspergillus niger based on microbial observation, colony growth, morphological characteristics and hyphae, was identified as Aspergillus niger (Fig 1). Withania somnifera leaf is also been used in the isolation of endophytes and synthesis of silver nanoparticles [17]. Aspergillus terreus, Aspergillus fumigatus and Aspergillus Niger were used in the synthesis of Silver Nanoparticles [18-20].
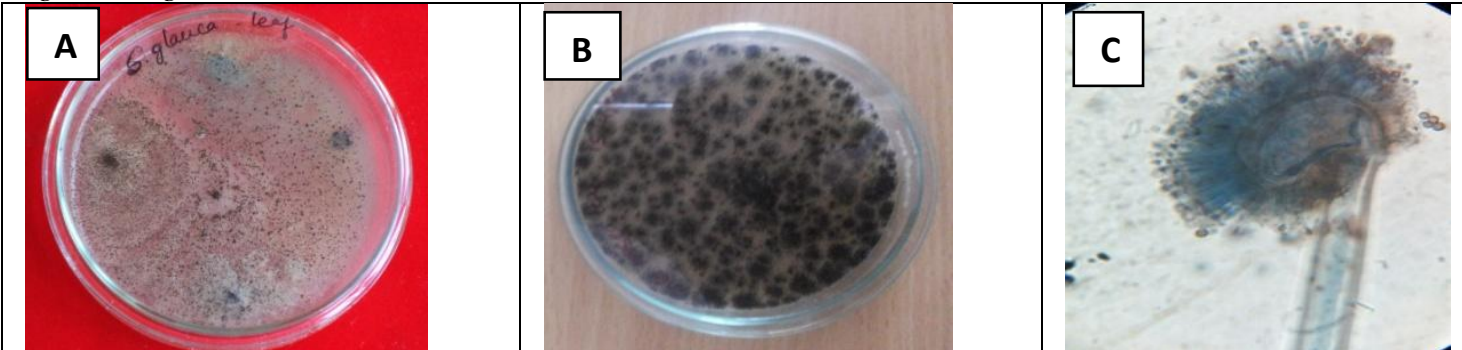

Fig 1. A) Inoculation of leaf on PDA medium. B) Growth of endophytic fungus on the PDA medium after the incubation period of 7 days. C) Aspergillus niger.

\section{Synthesis of Silver nanoparticles}

Silver ions were reduced to silver nanoparticles when added endophytic extracts and it was observed that the color of the mixed solution turned from pale yellowish to dark brown which indicated the formation of silver nanoparticles due to surface Plasmon resonance after $24 \mathrm{~h}$ of incubation (Fig 2) [21-24]. The formation and stability of silver nanoparticles in the solution are confirmed by UV-vis spectrophotometer studies.
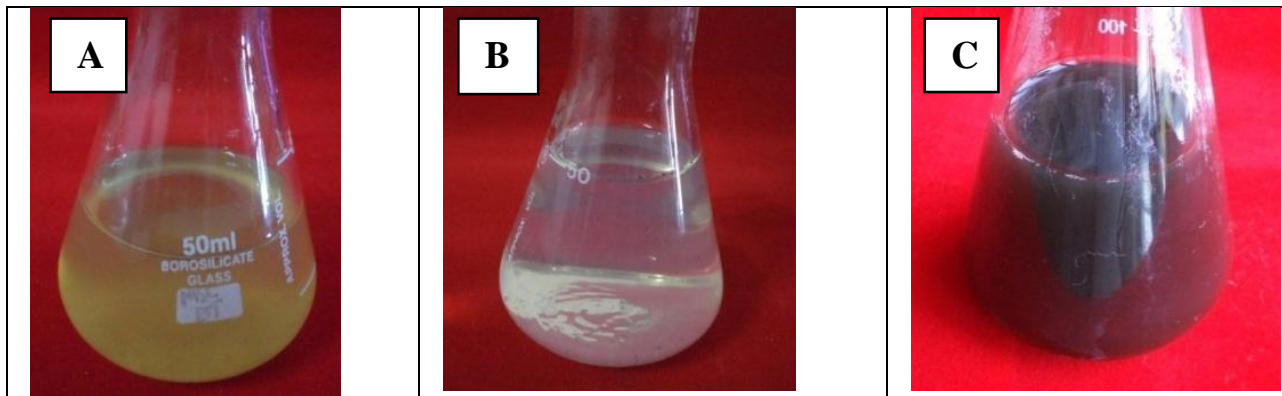

Fig 2. A) Endophytic extract, B) just after the addition of silver nitrate, C) After 24 hours of incubation in dark condition.

\section{Characterization of silver nanoparticles}

Synthesis of silver nanoparticles from endophyte Aspergillus extract isolated from Simarouba glauca has showed astounding strong broad spectra of $400 \mathrm{~nm}$. [25-28]. This was further confirmed by $\mathrm{X}$ ray diffraction analysis, the lattice plane indexed to the (111), (200), (220), (311) with the Bragg reflections with $2 \theta$ values of $38^{0}, 44^{0}, 64^{0}$, $77^{0}$, (JCPDS file no. 4-783). G Rajakumar et al also reported the XRD patterns for which XRD pattern of our sample resembles which suggests that the synthesized silver nanoparticles from endophyte
Aspergillus niger isolated from Simarouba glauca are biphasic in nature. [29-33].

The functional group was confirmed by FTIR analysis, a broad band between $3289 \mathrm{~cm}^{-1}$ is due to strong O-H stretching intermolecular bond of alcohol, the band at $2916 \mathrm{~cm}^{-1}$ corresponds to medium C-H stretching Alkenes, the medium band at $1597 \mathrm{~cm}^{-1}$ corresponds to $\mathrm{N}-\mathrm{H}$ bending amine, the medium band at $1387 \mathrm{~cm}^{-1}$ corresponds to $\mathrm{C}-\mathrm{H}$ bending aldehyde, the strong band at $1062 \mathrm{~cm}^{-1}$ corresponds to $\mathrm{C}-\mathrm{O}$ stretching primary alcohol, the strong band at 536 indicates C-L stretching halo compound (Fig 3) $[34,35]$. 


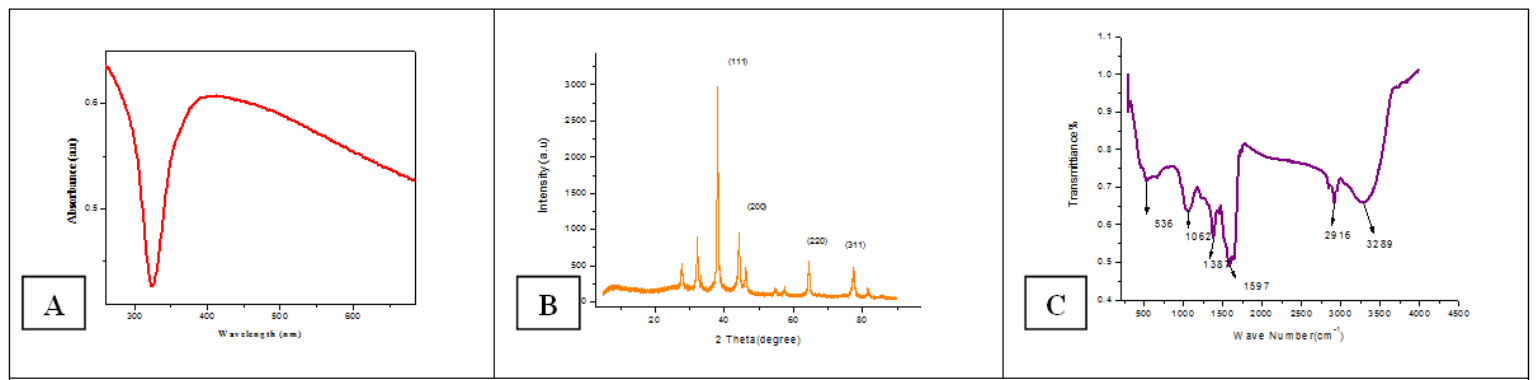

Fig 3. A) UV visible spectra showing strong broad peak at $400 \mathrm{~nm}$ of silver nanoparticles synthesized by Aspergillus niger extracts. B) X-ray crystallographic studies of silver nanoparticles. C) FT- IR spectra of silver nanoparticles.

Scanning Electron Microscopy analysis was performed to study size and surface morphology of the silver nanoparticles synthesized from endophyte Aspergillus niger extracts. The average particle size was $41.9 \mathrm{~nm}$ calculated using Debye- Scherrer equation (Fig 4) [36, 37]. EDX analysis suggested that silver and oxygen are present in the sample, also it confirmed that the sample contains silver nanoparticles (Fig 5).

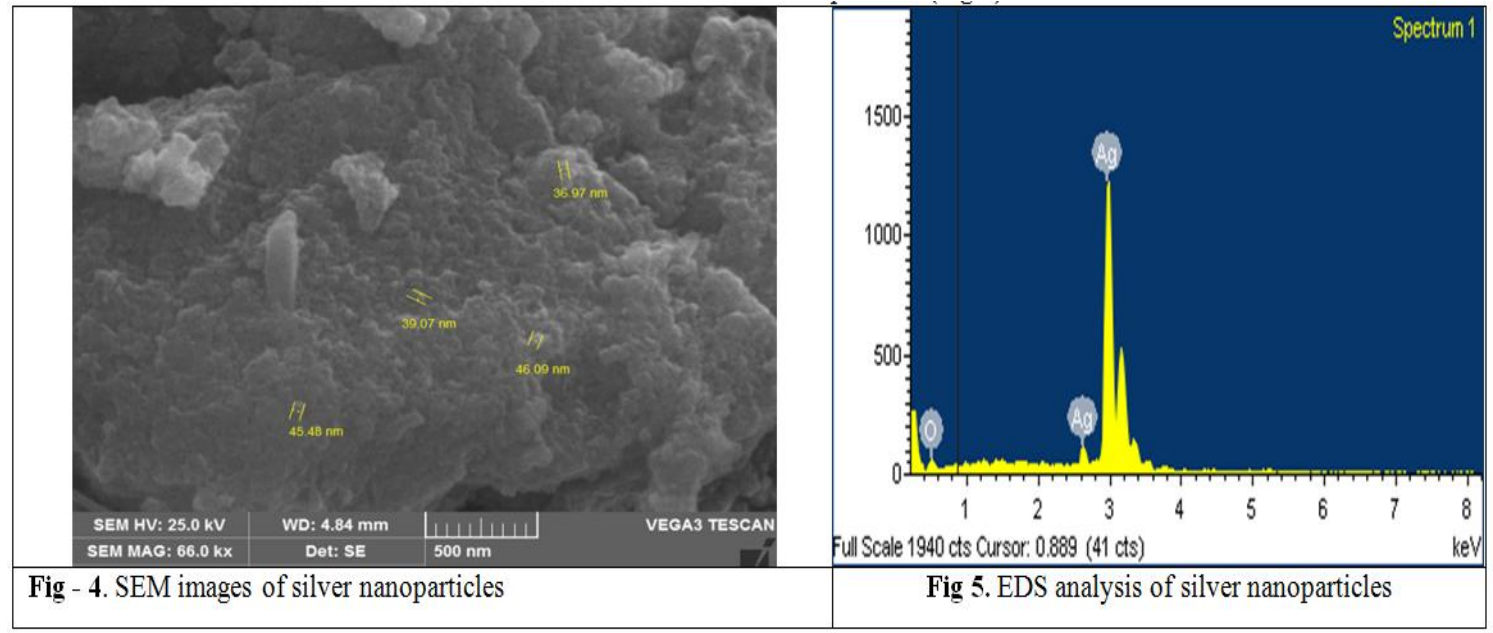

\section{ANTI- BACTERIAL ASSAY}

The antibacterial activity of silver nanoparticles and endophytic extract was performed by disc diffusion method. The results indicated that the endophytic extract alone was failed to exhibit antibacterial effect against the tested microorganisms. Nevertheless, silver naoparticles showed the significant antibacterial activity against the tested microorganisms (Fig 6, Table-1) [38, 39].

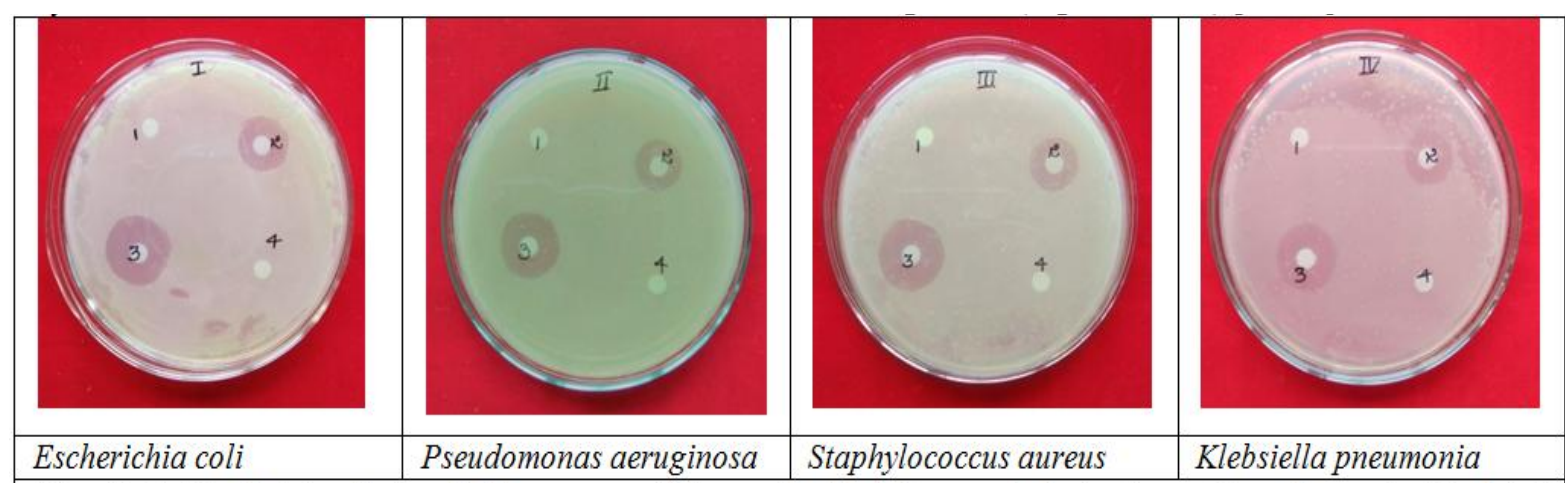

Fig - 6. Antibacterial activity of silver nanoparticles synthesized from endophyte Aspergillus niger extract isolated from Simarouba glauca leaf.

I. Escherichia coli, II. Pseudomonas aeruginosa, III. Staphylococcus aureus, IV. Klebsiella pneumonia. 1. Double distilled water, 2. Taxim (antibiotic), 3. AgNPs, 4. Endophytic extract. 


\begin{tabular}{|c|c|c|c|c|c|}
\hline S1. No & Test organisms & Control & Standard & Sample & Endophytic extract \\
\hline II & Pseudomonas spp & 0 & $15 \pm 1.3^{\mathrm{a}}$ & $21 \pm 1.6^{b}$ & 0 \\
\hline III & Staphylococcus spp & 0 & $18 \pm 1.5^{\mathrm{a}}$ & $24 \pm 1.2^{b}$ & 0 \\
\hline IV & Klebsiella spp & 0 & $17 \pm 1.0^{\mathrm{a}}$ & $20 \pm 1.4^{a}$ & 0 \\
\hline
\end{tabular}

Values were expressed as the means of three replicates \pm SD.

\section{ANTIOXIDAT ASSAY DPPH ASSAY}

The synthesized nanoparticles and Ascorbic acid showed the percentage inhibition graphically and the
$\mathrm{IC}_{50}$ value was found to be $58 \mu \mathrm{g} / \mathrm{ml}$ and $147 \mu \mathrm{g} / \mathrm{ml}$ for ascorbic acid and silver nanoparticles respectively (Fig7) [40]. Many authors suggested that synthesized silver nanoparticles can be used as strong antioxidants (41).

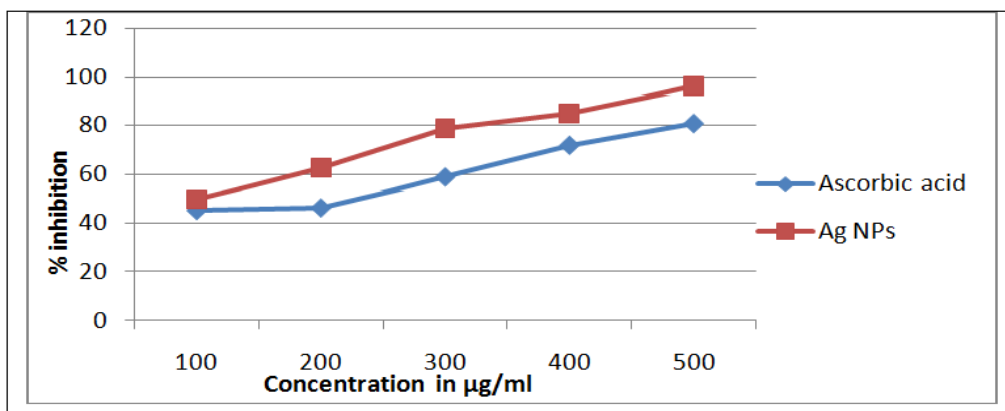

Fig - 7. Free radical scavenging of Ascorbic acid and Silver nanoparticles synthesized from endophyte Aspergillus niger extract isolated from Simarouba glauca leaf against $\mathrm{DPPH}$ at $517 \mathrm{~nm}$.

\section{ANTIMITOTIC ASSAY}

The outcomes of antimitotic assay for synthesized silver nanoparticles, distilled water, Quercetin in different stages of cell cycle are depicted in figure-
$10,11,12$ and table 2 . The meristem division of the Allium cepa is similar to the cancer cell division and hence we have selected the same for evaluation of anticancer activity of silver nanoparticles [42].
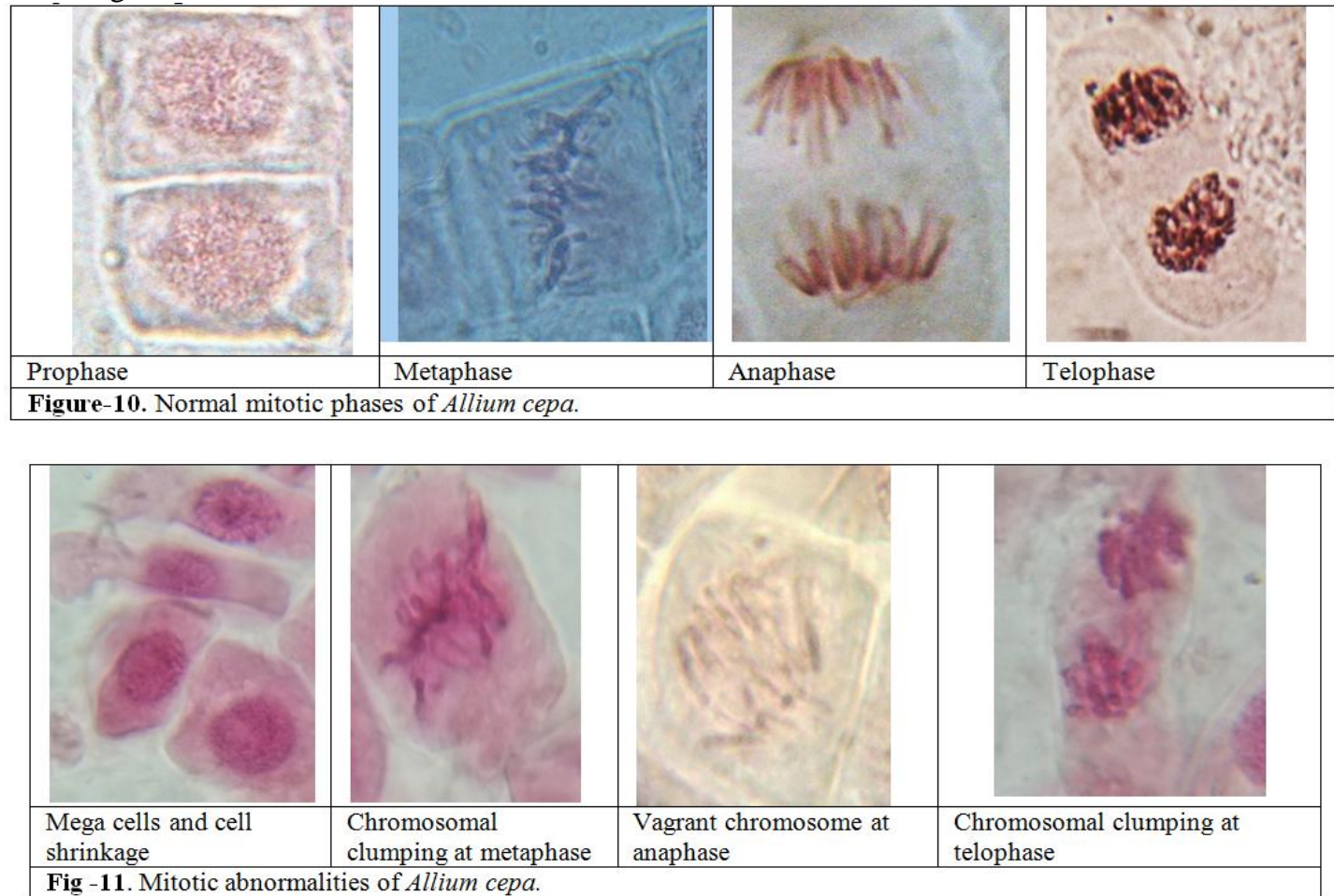


\begin{tabular}{|l|l|l|l|}
\hline \multicolumn{4}{|c|}{ Table 2. Antimitotic activity of silver nanoparticles } \\
\hline Sl. No. & Sample & Concentration & Mitotic index \\
\hline 1 & Distilled water & -------- & 94.22 \\
\hline 2 & Ag NPs & $10 \mathrm{mg} / \mathrm{ml}$ & 25.19 \\
\hline 3 & Ag NPs & $5 \mathrm{mg} / \mathrm{ml}$ & 32.52 \\
\hline 4 & Quercetin (Standard) & $1 \mathrm{mg} / \mathrm{ml}$ & 23.98 \\
\hline
\end{tabular}

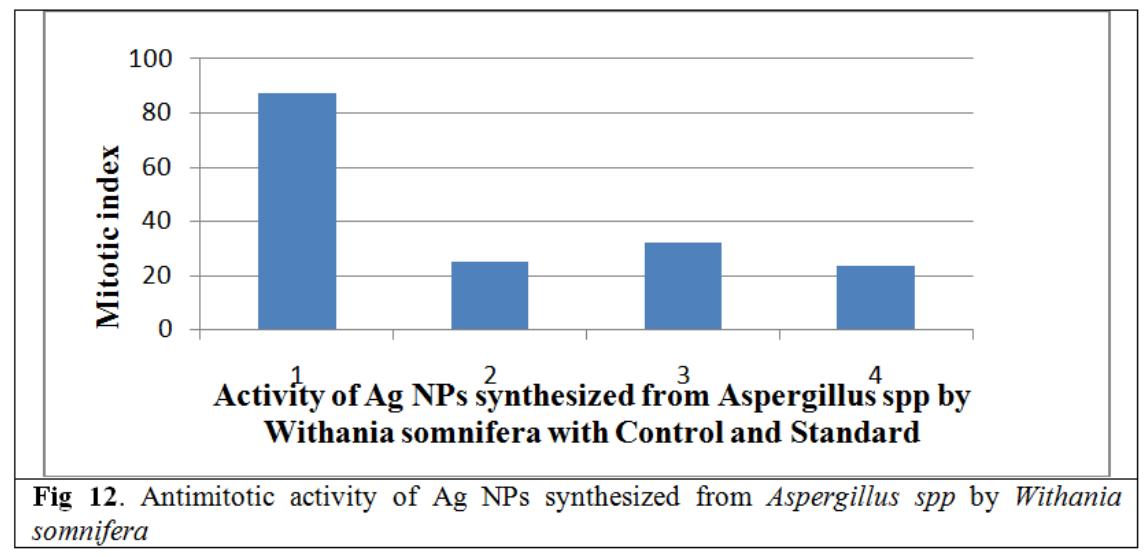

\section{CONCLUSION}

The present study revealed that silver nanoparticles can be synthesized by aqueous extract of Aspergillus niger isolated from Simarouba glauca leaf. SEM analysis showed that the sizes of the synthesized AgNps ranged from 36.97 to $46.07 \mathrm{~nm}$. Synthesized silver nanoparticles displayed excellent antibacterial activity against tested microorganisms comparatively with standard antibiotic used. A significant antioxidant activity was also shown by silver nanoparticles and it woukd be appropriate for the development of new drugs for various ailments.

\section{ACKNOWLEDGEMENT}

We express our sincere gratitude to Dr M R Hulinaykar, Honorable Managing Trustee, Sri Shridevi Charitable Trust, Tumakuru, Karnataka, India and Dr Gurulingappa M Patil, Principal, Shridevi Institute of Engineering and Technology, Sira Road, Tumkur, Karnataka, India for their support, encouragement and extending all the necessary facilities in the college for the successful completion of this work. One of the authors Dr. G. Nagaraju thanks DST Nanomission. Govt. of India, New Delhi for financial support to carry out the research work (Project No. SR/NM/NS-1262/2013 (G) dated 18-03-2015).

\section{REFERENCES}

[1] D. Singh, V. Rathod, S. Ninganagouda, J. Herimath, P. Kulkarni, - Biosynthesis of silver nanoparticles by endophytic fungi Pencillium sp. Isolayed from Curcuma Longa (turmeric) and its antibacterial activity against pathogenic gram negative
[2] bacteria, Journal of Pharmacy Research, pp. 448- 453, 2013.

[3] R. Veerasamy, T. Zi. Xin, S. Gunasagaran, T. F. Wei Xiang, E.F Chou Yang, N. Jeyakumar, S.A. Dhanaraj, - Biosynthesis of silver nanoparticles using mangosteen leaf extract and evaluation of their antimicrobial activities, Journal of Saudi Chemical Society, pp. 113-120, 2011.

[4] H.M.M. Ibrahim, - Green synthesis and characterization of silver nanoparticles using banana peel extract and their antimicrobial activity against representative microorganisms, Journal of Radiation Research and Applied Sciences, pp. 265275, 2015.

[5] A.G. Ingale, A.N. Chaudhari, - Biogenic synthesis of nanoparticles and potential applications: An eco friendly approach, J. Nanomed. Nanotechol, pp.1-7, 2013.

[6] K. Kathiresan, S. Manivannan, M.A. Nabeel, B. Dhivya, - Studies on silver nanoparticles synthesized by a marine fungus, Penicillium fellutanum isolated from coastal mangrove sediment, Colloids Surf. B Biointerfaces, pp. 133-137, 2009.

[7] M.A. Farooqui, P.S. Chauhan, P. Krishnamoorthy, J. Shaik, - Extraction of silver nanoparticles from the leaf extracts of clerodendrum inerme, Digest Journal of Nanomaterials and Biostructures, pp. 43- 49, 2010.

[8] K.P. Upendra, S.S. Preeti, S. Anchal, Bioinspired synthesis of silver nanoparticles, Digest Journal of Nanomaterials and Biostructures, pp. 159-166, 2009. 
[9] V.L. Das, R. Thomas, T.V. Rintu, E.V. Soniya, J. Mathew, E. K. Radhakrishnan, Extracellular synthesis of silver nanoparticles by the Bacillus strain CS 11 isolated from industrialized area, 3 Biotech, pp. 121-126, 2014.

[10] Guangquan Li, Dan He, Y. Qian, B. Guan, Song Gao, Yan Cui, K. Yokoyama, Li Wang, - Fungus mediated green synthesis of silver nanoparticles using Aspergillus terreus, International Journal of molecular science, pp. 466-476, 2012.

[11] M. Kowshik, S. Ashtaputre, S. Kharrazi, W. Vogel, J. Urban, S.K. Kulkarni and K. M. Paknikar, - Extracellular synthesis of silver nanoparticles by a silver-tolerant yeast strain MKY3, Nanotechnology, pp. 95-100, 2002.

[12] S. Ahmed, M. Ahmad, B.L. Swami, S. Ikram. - A review on plants extract mediated synthesis of silver nanoparticles for antimicrobial applications: A green expertise, Journal of Advanced Research, pp. 17-28, 2016

[13] S. Iravani, H. Korbekandi, S.V. Mirmohammadi, B. Zolfaghari, - Synthesis of silver nanoparticles: chemical, physical and biological methods. Res Pharm Sci. pp. 385-406, 2014.

[14] J.L. Elechiguerra, J. L. Burt, J.R. Morones, A.C. Bragado, X. Gao, H. H Lara, M.J. Yacaman, - Interaction of silver nanoparticles with HIV-I, Journal of Nanobiotechnol, pp. 1-10, 2005.

[15] L.K. Santhana, D. Sangeetha, S. Sivamani, M. Tamilarasan, T.P. Rajesh, B. Anandraj, In vitro antibacterial, antioxidant, haemolytic, thrombolytic activities and phytochemical analysis of Simarouba glauca leaves extracts, International Journal of Pharmaceutical Sciences and Research, pp. 432-437, 2014.

[16] A.K. Singh, V. Rathod, D. Singh, S. Ninganagouda, Prema Kulkarni, Jasmine Mathew, Manzoor ul Haq, - Bioactive Silver nanoparticles from endophytic fungus Fusarium sp. Isolated from an ethnomedical plant Withania somnifera (Ashwagandha) and its antibacterial activity, International Journal of Nanomaterials and Biostructures, pp. 15-19, 2015.

[17] C.P. Chandrappa, M.Govindappa, N. Chandrasekar, Sonia Sarkar, Sepuri Ooha, R. Channabasava, - Endophytic synthesis of silver chloride nanoparticles from Penicillium sp. of Calophyllum apetalum Advances in Natural Sciences: Nanoscience and Nanotechnology, pp. 1-5, 2016.
[18] C. Kuber, S.F.Bhainsa. D'Souza, Extracellular biosynthesis of silver nanoparticles using the fungus Aspergillus fumigates, Colloids and surfaces B: Biointerfaces, pp. 160-164, 2006.

[19] A. Braca, N. De Tommasi, L. Di Bari, C.Pizza, M. Politi, I. Morelli, - Antioxidant principles from Bauhinia terapotensis, J. Nat. Prod, pp. 892-895, 2001.

[20] C.P.Chandrappa, M.Govindappa, N.V.Anil Kumar, - In vitro antimitotic, antiproliferative and DNA fragmentation assay of ethanol extract of Carmona retusa (Vahl.) Masam, ACB, pp. 52-57, 2013.

[21] Y.K. Mohanta, S.K. Panda, R. Jayabalan, N. Sharma, A.K. Bastia, T.K. Mohanta, Antimicrobial, Antioxidant and Cytotoxic Activity of Silver Nanoparticles Synthesized by Leaf Extract of Erythrina suberosa (Roxb.), Frontiers in Molecular Biosciences, pp. 14. 1-9, 2017.

[22] A. K. Gade, P. Bonde, A. P. Ingle, P. D. Marcato, N. Duran, M. K. Rai, Exploitation of Aspergillus Niger for Synthesis of Silver Nanoparticles, Journal of Biobased Materials and Bioenergy, pp. 1-5, 2008.

[23] A. Bankar , B. Joshi , A. Ravi Kumar, S. Zinjarde, - Banana peel extract mediated novel route for the synthesis of silver nanoparticles, Colloids and Surfaces A: Physicochemical and Engineering Aspects, pp. 58-63, 2010.

[24] M. Rai , A. Yadav, A. Gade, - Silver nanoparticles as a new generation of antimicrobials, Biotechnology Advances, pp. 76-83, 2009.

[25] R.Nithya, R.Ragunathan, - Synthesis of silver nanoparticle using pleurotus sajor caju and its antimicrobial study, Digest Journal of Nanomaterials and Biostructures, pp. 623 $-629,2009$.

[26] Y. rong Ma,H. yun Niu, X.le Zhang, Y. qi Cai, - Colorimetric detection of copper ions in tap water during the synthesis of silver/dopamine nanoparticles, ChemComm, pp. 12643-12645, 2011.

[27] Y.Kobayashi, H. Katakami, E. Mine, D. Nagao, M. Konno, L.M. Liz-Marzan, Silica coating of silver nanoparticles using a modified Stober method, Journal of Colloid and Interface Science, pp. 392-396, 2005.

[28] K. C. Song, S.M. Lee, T.S.Park, B.S.Lee, Preparation of colloidal silver nanoparticles by chemical reduction method, Korean J. Chem. Eng., pp. 153-155, 2009.

[29] A. Frattini, N. Pellegri, D. Nicastro, O. de Sanctis, - Effect of amine groups in the 
synthesis of $\mathrm{Ag}$ nanoparticles using aminosilanes, Materials Chemistry and Physics, pp. 148-152, 2005.

[30] S.A. Cumberland, J.R. Lead, - Particle size distributions of silver nanoparticles at environmentally relevant conditions, Journal of Chromatography A, Journal of Chromatography A, pp. 9099-9105, 2009.

[31] S. Shiv Shankar, A. Ahmad, M. Sastry, Geranium Leaf Assisted Biosynthesis of Silver Nanoparticles, Biotechnol. Prog, pp. 1627-1631, 2003.

[32] H. Bar, D.K. Bhui, G.P. Sahoo, P. Sarkar, S.P. De, A. Misra, - Green synthesis of silver nanoparticles using latex of Jatropha curcas, Colloids and Surfaces A: Physicochemical and Engineering Aspects, pp.134-139339, 2009.

[33] K. Kalimuthu, R.S. Babu, D. Venkataraman, Mohd. Bilal, S. Gurunathan, - Biosynthesis of silver nanocrystals by Bacillus licheniformis, Colloids and Surfaces B: Biointerfaces, pp. 150-153, 2008.

[34] S. Basavaraja, S.D. Balaji, A. Lagashetty, A.H. Rajasab, A. Venkataraman, Extracellular biosynthesis of silver nanoparticles using the fungus Fusarium semitectum, Materials Research Bulletin, pp. 1164-1170, 2008.

[35] M.Raffi, F.Hussain, T.M.Bhatti, J.I.Akhter, A.Hameed, M.M.Hasan, - Antibacterial Characterization of Silver Nanoparticles against E. Coli ATCC-15224, J. Mater. Sci. Technol., pp. 192-196, 2007.

[36] Prietop, M. Pineda, M. Aguilar, Spectrophotometeric quantitation of antioxidant capacity through the formation of a phosphomolybdenum complex specific application to the Determination of vitamin, E Anal Biochem, pp. 337-341, 1999.

[37] G Rajakumar, A.A. Rahuman, - Larvicidal activity of synthesized silver nanoparticles using Eclipta prostrate leaf extract against filariasis and malaria vectors, Acta Tropica, pp. 196-203, 2011.

[38] M.M.H. Ibrahim, - Green synthesis and characterization of silver nanoparticles using banana peel extract and their antimicrobial activity against representative microorganisms, Journal of Radiation Research and Applied Sciences, pp. 265275, 2015.

[39] N.N. Devi, D.Shankar, Sutha, - Biomimetic synthesis of silver nanoparticles from an endophytic fungus and their antimicrobial efficacy, International Journal of Biomedical and Advance Research, pp. 309-315, 2012.

[40] D. Jain, H. K. Daima, S. Kachhwaha, S. L. Kothari, - Synthesis of plant-mediated silver nanoparticles using papaya fruit extract and evaluation of their anti microbial activities, Digest Journal of Nanomaterials and Biostructures, pp. 557 - 563, 2009.

[41] C.P.Chandrappa, M. Govindappa, N Chandrashekhar, S. Sonia, S. Ooha, R. Channabasava - Endophytic synthesis of silver nanoparticles from Penicillium sp. of Calophyllum apetalum, Adv. Nat. Sci.: Nanosci. Nanotechno, pp. 1-5, 2016.

[42] V. Dhand, L. Soumya, S. Bharadwaj, S. Chakra, D. Bhatt, B. Sreedhar, Green synthesis of silver nanoparticles using Coffea arabica seed extract and its antibacterial activity, Materials Science and Engineering, pp. 36-43, 2016

[43] T.A. Nagalakshmi, A. U.S.R. Mahadeva, Study of Cytotoxic and Antimitotic Activities of Solanum nigrum by Using Allium cepa Root Tip Assay and Cancer Chemo preventive Activity Using MCF-7Human Mammary Gland Breast Adenocarcinoma Cell Lines, International Journal of Science \& Technology, pp. 2648, 2011.

\footnotetext{
International Journal of Engineering Research and Applications (IJERA) is UGC approved Journal with Sl. No. 4525, Journal no. 47088. Indexed in Cross Ref, Index Copernicus (ICV 80.82), NASA, Ads, Researcher Id Thomson Reuters, DOAJ.

Hemashekhar B. "Green synthesis of silver nanoparticles from Endophytic fungus Aspergillus niger isolated from Simarouba glauca leaf and its Antibacterial and Antioxidant activity." International Journal of Engineering Research and Applications (IJERA) 7.8 (2017): 17-24.
} 